\title{
PHYTOPLANKTON COMPOSITION IN A MEDIUM-SIZED MEDITERRANEAN RIVER: THE TER (SPAIN)
}

\author{
S. Sabater \\ Departament d'Ecologia, Facultat de Biologia, Universitat de Barcelona. Avda. Diagonal 645, 08028 Barcelona. \\ Spain.
}

Keywords: phytoplankton, Mediterranean river, eutrophic conditions, benthos, Spain.

\begin{abstract}
Phytoplankton developed in quiet areas of the middle and lower stretch of the river Ter (Catalonia, NE Spain). Euplanktonic assemblages were restricted to the nver mouth. Centric diatoms were scarce, and a great influence of diatom benthic species was observed. Green algae were the dominant taxonomic group in the river.

The phytoplankton assemblages of the river Ter are intermediate between the fast-flowing, individual-poor streams and the large, slow-moving, individual-rich streams. Its medium size and the high nutrient concentrations are the main factors responsible for its particular characteristics.
\end{abstract}

\section{INTRODUCTION}

The river Ter is situated in NE Catalonia (NE Spain). It is a typical Mediterranean (irregular hydrological regime), medium-sized nver. Because it drains an industrial and agricultural area it is regulated and has a great variety of inputs. It flows over a distance of $208 \mathrm{~km}$ to the Mediterranean sea (fig. 1). From its source in the Pyrenees $(2500 \mathrm{~m}$ altitude), its slope quickly decreases until the city of Ripoll; from there it flows more slowly to Girona and the sea. Three reservoirs are arranged in the middle stretch of the river. The flow river regime shows some Alpine influence in its upper part, but in the rest it is typically Mediterranean; i.e. flow is low when snow accumulates in the mountains in January, and increase in March due to snow melt. It has a pronounced minimum during summer, and in the autumn there are frequent floods because of the high rains. The average flow (over the period 1972-1982) of the river at the mouth is $29 \mathrm{~m}^{3} \mathrm{~s}^{-1}$.

True phytoplankton develop in the lower stretches of medium and small size rivers when

Limnetica, 6: 47-56 (1990)

(C) Asociación Española de Limnología, Madrid, Spain the current becomes slow (MARGALEF 1983). These systems typically show a striking abundance of benthic species. The importance of distinguishing difference between the organisms swept up off the bottom and the true plankters has been emphasized by HyNes (1970). It has also been observed (Holmes \& WhitTon 1981) that plankton can develop in pool areas or among the aquatic plants of the river banks. In Mediterranean rivers the hydrological regime (dry seasons alternating with high water seasons or floods) should favour the benthos influence and lead to a poverty of the true plankters, because these systems are unstable.

The phytoplankton of Mediterranean European rivers is poorly known. The only noteworthy studies are CAPBlanc \& DAUTA (1978) and DAUTA (1975) on the river Lot (France) and ANDREOLI \& FrICANo (1981) on the river Po (Italy). This contrasts with an abundance of studies on this subject in the non-Mediterranean area (West Europe: Descy 1987, Holmes \& Whitton 1981, LaCK 1971, Lange-Bertalot 1974, Moore 1976, Peelen 1975, SkUlberg \& Lillehammer 1984; East Europe: Dobler \& SChMidT 1980, KuZmin 1978). Therefore, more information on phytoplankton in Mediterranean rivers is required in order to understand 
the behaviour of these systems. In this paper some data on the phytoplankton composition and abundance of the river Ter are presented. Moreover, a comparison with some other phytoplanktonic assemblages in European rivers is discussed.

\section{MATERIALS AND METHODS}

As part of a more extensive algal study in the Ter basin (SABATER 1989, 1990, SABATER \& SABATER 1988), a survey along the whole river was carried out in order to establish the development of phytoplankton at different sites. Therefore, tentative phytoplankton samples were taken every $5 \mathrm{~km}$ from the outflow of the reservoirs to the mouth. However, subsurface samples were taken mainly in two sites near the mouth of the river. The first of them (site 48) was $1000 \mathrm{~m}$ upstream from the river mouth, where the river was relatively deep (2-4 m on average). Vegetation on the rivers banks was formed by tamarinds (Tamarix gallica) and reeds (Arundo donax, Erianthus ravennae). The second site (site 53), was located close to the mouth, between a little island and
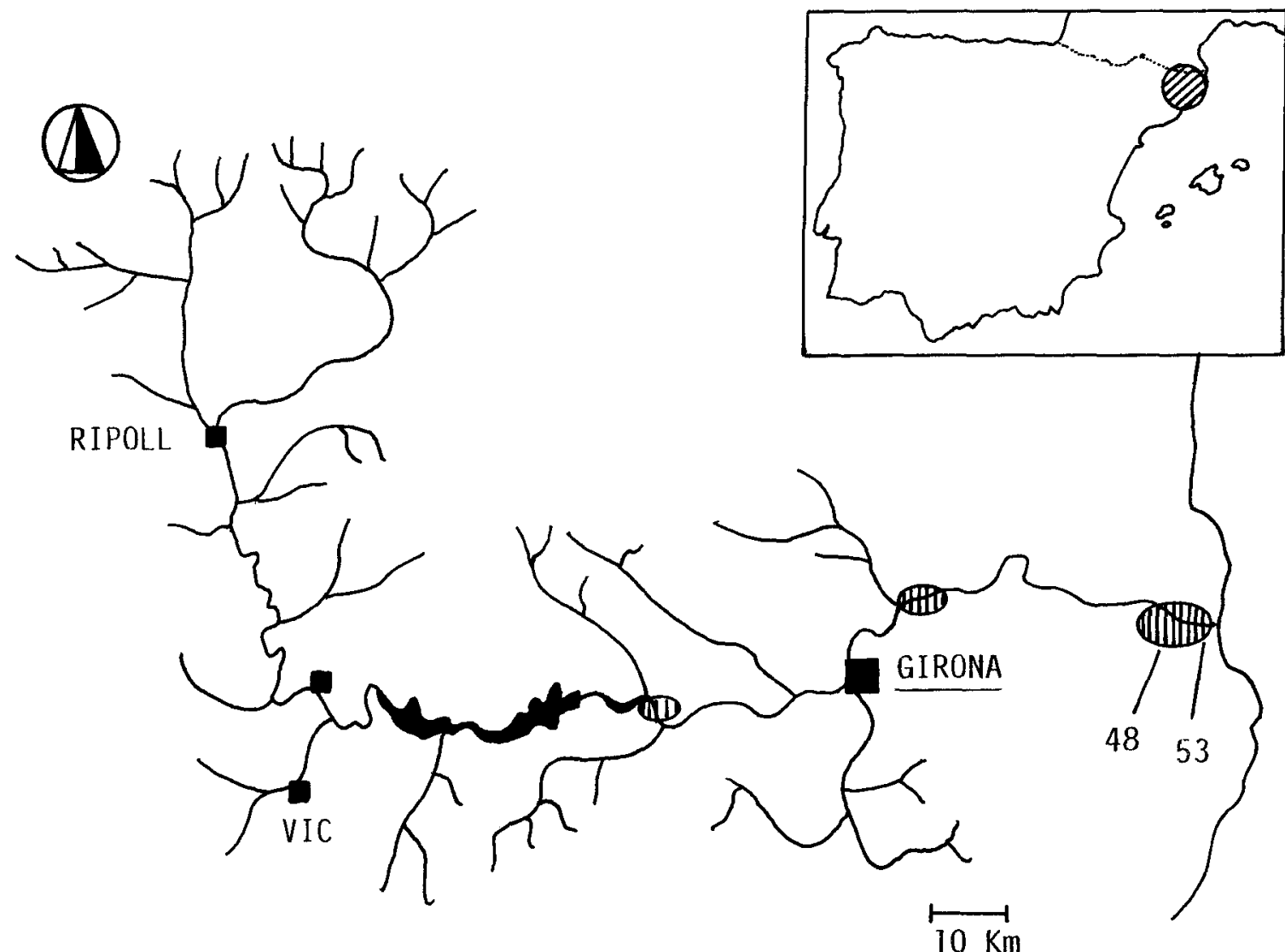

Figure 1.- Situation of the nver Ter (circle) with respect to the Ibenan Peninsula. Enlarged, there is a map of the nver Ter basin, where its main tributaries and towns scattered along its banks are pictured. Shaded segments represent the stretches where plankton development has been observed.

Situación del río Ter en la Península Ibérica (círculo). Ampliado aparece el mapa de la cuenca del no, indicándose sus principales afluentes y las ciudades que se disponen en su curso. Los segmentos sombreados indican los lugares donde se observó desarrollo de fitoplancton. 
a sandy bar. The waters were shallow and a macrophytic vegetation of Potamogeton sp. and Miriophyllum sp. developed.

Collections were done between 1984 and 1987. Samples were taken seasonally, during the more significant hydrological periods (winter, spring, summer). In all the cases, phytoplankton was collected with $250 \mathrm{ml}$ glass bottles. Samples were presewed with Lugol's solution $(\mathbf{I}+\mathbf{K I})$, and in a few cases with $4 \%$ formol. An inverted microscope with a magnification of $\times 1000$ was used to identify the organisms; $a \times 400$ magnification was used for counting. In order to compare the samples, phytoplankton counts are expressed in relative percentages for each sample. In the counting, cells, colonies or filaments were considered as a unit. Live diatoms were counted separately from dead frustules. Identification followed GeITLER (1932), Germain (1981), Komarek \& Fott (1983), Krammer \& Lange-Bertalot (1986) and KleE \& SteInberg (1987). Scanning Electron Microscopical observations were carried out for determination of doubtful taxa, mainly on centric diatoms. The analyzed material was gold coated and observed with a Cambridge S-120 and a Jeol 840; fresh material was previously critical point dried. The Shannon-Weaver diversity index in base e (SHANNON \& WEAVER, 1963) was calculated for each sample.

Temperature, $\mathrm{pH}$, conductivity and dissolved oxygen were measured simultaneously. In some cases, water samples were taken to the laboratory in order to determine concentrations of nutrients (phosphates, nitrates, nitrites, ammonia) and major ions (sulphates, chlorides, silicates). The APHA (1980) procedures were followed.

\section{RESULTS}

In a first survey samples of phytoplankton were collected approximately every $5 \mathrm{~km}$ from the main stretch of the river starting at the output of the third resewoir (El Pasteral) and ending at the mouth. Phytoplankton development was only obsewed in the shaded segments that are represented in figure 1: below the resewoirs, after the city of Girona and in the proximity of the mouth.

Water in the two sites near the mouth was alkaline, nutrient-rich and progressively important in ionic strength, because of the vicinity of the sea (table 1). In a site close to the outflow of the reservoirs, water was highly mineralized, but nutrient content was moderate. Just downstream of Girona, pollution was obvious, with high amount of human and industrial wastes. In all that sites, changes in time of the variable concentrations (major ions, nutrients) were related in a great extent to the recorded in the flow (SABATER \& ARMENGOL , 1988), although the resewoirs act as regulators. Fluctuations were lower when closer to the mouth (SABATER, 1987).

The number of cells per milliliter ranged from $9,000-12,000$ in winter and spring, up to more than 50,000 in summer $(92,000$ at site 53$)$. Diversity in the samples was always quite low, but it was slightly higher at site 53. The lowest values (0.4-0.6 bits) were found in winter at site 48 . In spring and summer values reached 1.1-1.5 at both sites (table 2).

Seventy four algal taxa were observed in the phytoplankton samples in the river Ter. Of the non-diatom species, only some of the taxa were not found in benthic samples (table 2). It can

Table 1.- Physico-chemical characteristics of the water in the sites where development of phytoplankton was detected. The given values are the average of twelve monthly sampling periods (October 1982 to September 1983), except in the case of site 53, where they are the mean of those corresponding to 29th April 1984 and 15th September 1987.

Características físico-químicas del agua en los puntos en que se observó desarrollo de fitoplancton. Los valores corresponden a la media de doce períodos mensuales de muestreo (de octubre de 1982 a septiembre de 1983). En el caso de la estación 53 los valores corresponden a la media entre los obtenidos el 29 de abril de 1984 y el 15 de septiembre de 1987.

\begin{tabular}{|c|c|c|c|c|c|c|c|c|c|c|c|c|}
\hline & $p H$ & $\begin{array}{c}\text { Oxygen } \\
(m g / l)\end{array}$ & $\begin{array}{c}\text { Temp. } \\
\left({ }^{\circ} \mathrm{C}\right)\end{array}$ & $\begin{array}{c}\text { Cond. } \\
(\mu S / c m)\end{array}$ & $\begin{array}{c}\text { Alkalinity } \\
\text { (meq./l) }\end{array}$ & $\begin{array}{l}\mathrm{NO}_{3} \\
(\mu \mathrm{M})\end{array}$ & $\begin{array}{l}\mathrm{NO}_{2}^{-} \\
(\mu M)\end{array}$ & $\begin{array}{l}\mathrm{NH}_{4}^{+} \\
(\mu M)\end{array}$ & $\begin{array}{l}P O_{4}^{\equiv} \\
(\mu M)\end{array}$ & $\begin{array}{l}\mathrm{SO}_{4}^{=} \\
(\mu M)\end{array}$ & $\begin{array}{l}\mathrm{SiO}_{4} \\
(\mu M)\end{array}$ & $\begin{array}{c}\text { Flow } \\
\left(\mathrm{m}^{3 / s}\right)\end{array}$ \\
\hline Downst, reservoirs & 7.8 & 8.7 & 15.6 & 460 & 3.2 & 50.2 & 4.8 & 8.3 & 4.2 & 0.5 & 93.0 & 12.7 \\
\hline Downst, Girona & 7.6 & 9.6 & 15.5 & 492.4 & 3.1 & 43.3 & 16.2 & 92.2 & 19.4 & 1.1 & 78.7 & 19.6 \\
\hline Site 48 & 8.2 & 9.4 & 24.7 & 2,350 & 4.0 & 24.7 & 9.1 & 12.7 & 15.7 & 3.6 & 71.4 & 11.3 \\
\hline Site 53 & 8.3 & 4.7 & 26.2 & 4,550 & - & $\mathbf{5 7 . 0}$ & 10.27 & $-m$ & 26.88 & 5.5 & 43.09 & - \\
\hline
\end{tabular}


Table 2.- Floristic composition, abundances and diversity of euplanktonic taxa of phytoplankton assemblages in sites 48 and 53 , both near the mouth of the nver. Relative abundances are expressed in percentages. The sign * designates taxa found only in plankton samples.

Composición florística, abundancia y diversidad de las poblaciones de fitoplancton en las estaciones 48 y 53 , ambos en las cercanías de la desembocadura del no. Las abundancias relativas están expresadas en porcentajes. El signo ${ }^{*}$ indica los taxones observados únicamente en las muestras de fitoplancton.

\begin{tabular}{|c|c|c|c|c|c|c|c|c|c|c|}
\hline \multirow[b]{3}{*}{ Species } & \multicolumn{6}{|c|}{ Site 48} & \multicolumn{4}{|c|}{ Site 53} \\
\hline & \multirow{2}{*}{$\begin{array}{c}1984 \\
\text { March }\end{array}$} & \multirow{2}{*}{$\begin{array}{l}1985 \\
\text { Dec. }\end{array}$} & \multirow{2}{*}{$\begin{array}{c}1986 \\
\text { March }\end{array}$} & \multicolumn{3}{|c|}{1987} & \multirow{2}{*}{$\begin{array}{c}1984 \\
\text { March }\end{array}$} & \multirow{2}{*}{$\begin{array}{l}1985 \\
D e c\end{array}$} & \multicolumn{2}{|c|}{1987} \\
\hline & & & & Jan. & March & Sept. & & & Jan. & Sept. \\
\hline \multicolumn{11}{|l|}{ CYANOPHYTA } \\
\hline Anabaena constricta (Szaf.) Geit. & 0,3 & & 0,4 & & & & & & & \\
\hline Merismopedia tenuissima Lemm. & & 1,0 & & 0,2 & & & & 1,2 & 1,6 & 0,2 \\
\hline Phormidium frigidum Fritsch & & & 0.8 & & & & & & & \\
\hline \multicolumn{11}{|l|}{ EUGLENOPHYTA } \\
\hline Euglena sp. $\left({ }^{*}\right)$ & + & 0,3 & 2,7 & 7,8 & . & . & + & . & 23,5 & . \\
\hline Phacus sp. $\left({ }^{*}\right)$ & 1.7 & 0.3 & . & 0.5 & . & 0.2 & + & 1.6 & . & + \\
\hline \multicolumn{11}{|l|}{ CHLOROPHYCEAE } \\
\hline Actinastrum hantzschii Lagerh. $\left({ }^{*}\right)$ & & & . & 0.5 & . & . & & & 1.3 & . \\
\hline Ankistrodesmus falcatus (Corda) Ralfs & 43.7 & 0.3 & & 0.7 & . & 2.6 & 36.2 & 0.8 & 1.0 & 3.1 \\
\hline Coelastrum microporum Nag. in A. Br. $\left({ }^{*}\right)$ & & & & & 7.6 & 0.5 & & + & & 0.6 \\
\hline C. astroideum De-Not. $\left({ }^{*}\right)$ & & & & & . & 0.7 & . & . & . & 0.2 \\
\hline Chlamydomonas sp. $\left({ }^{*}\right)$ & 1.4 & 0.7 & & & 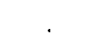 & & + & . & . & . \\
\hline Chlorella vulgaris Beij. & . & 83.1 & 88.7 & 81.9 & 84.6 & 22.4 & & 53.0 & 60.5 & 17.9 \\
\hline Crucigeniella apiculata (Lemm.) Kom. $\left({ }^{\star}\right)$ & & & & & . & 0.2 & & . & & 1.1 \\
\hline Dictyosphaerium pulchellum Wood $\left({ }^{*}\right)$ & & & & & . & . & + & . & 0.3 & . \\
\hline Golenkinia radiata Chod. $\left({ }^{*}\right)$ & & & & & . & & + & . & & . \\
\hline Kirchneriella subcapitata Jors. $\left({ }^{*}\right)$ & 2.8 & . & 0.8 & 1.7 & 0.6 & 57.6 & 1.3 & 6.5 & 2.9 & 56.6 \\
\hline Micractinium pusillum Fres. (') & . & . & & & . & 0.7 & . & 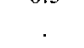 & 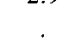 & 1.2 \\
\hline Monoraphidium griffithii (Berk.) Kom.-Leg. & 0.8 & . & & 0.2 & + & 0.5 & 1.3 & 0.4 & 0.3 & 0.2 \\
\hline M. contortum (Thuret in Breb.) Kom.-Leg. & & & & & . & 7.8 & & . & 0.6 & 10.3 \\
\hline Oocystis lacustris Chod. $\left({ }^{*}\right)$ & & & & & + & 2.9 & . & . & . & 1.4 \\
\hline Pediastrum boryanum (Turpin) Menegh & & & & & . & + & . & . & . & + \\
\hline P. duplex Meyen $\left({ }^{*}\right)$ & . & . & & & . & 0.2 & . & . & . & $\cdot$ \\
\hline Scenedesmus acuminatus (Lagerh.) Chod. $\left(^{*}\right)$ & . & . & & & . & . & + & . & & . \\
\hline S. acutus Chod. $\left({ }^{*}\right)$ & . & . & & & + & 0,5 & . & . & . & 0.9 \\
\hline S. apiculatus (W. \& G.S. West) Chod. $\left({ }^{\star}\right)$ & . & . & & & & & & . & . & + \\
\hline S. armatus Chod. $\left({ }^{*}\right)$ & & . & & & & & & . & . & + \\
\hline S. brevispina (G.M. Smith) Chod. $\left({ }^{*}\right)$ & . & . & . & 0.7 & . & 0.2 & & . & 2.3 & 0.2 \\
\hline S. longispina Chod. $\left({ }^{*}\right)$ & & & & & & & & . & . & + \\
\hline S. magnus Meyen $\left({ }^{*}\right)$ & & & & & & & & . & . & + \\
\hline S. ovalternus Chod. (*) & & & & & & + & & . & . & \\
\hline S. quadricauda (Turp.) Breb. $\left(^{\star}\right)$ & 3.3 & 2.4 & 0.8 & 0.5 & & 1.4 & 1.1 & 2.0 & + & 0.6 \\
\hline S. sempervirens Chod. $\left(^{*}\right)$ & & & & & & & & . & . & + \\
\hline S. spinosus Chod. $\left({ }^{*}\right)$ & & & . & . & . & . & . & . & & 0.2 \\
\hline S. subspicatus Chod. $\left({ }^{*}\right)$ & & & . & . & . & & . & . & & + \\
\hline Sphaerellopsis sp. $\left({ }^{*}\right)$ & & & . & & & . & . & 4.5 & & . \\
\hline Tetraedron minimum (A. Br.) Hansg. ( ${ }^{*}$ ) & & 0.7 & 0.3 & 0.3 & . & . & . & 0.4 & & + \\
\hline T. triangulare Kors. $\left({ }^{*}\right)$ & 2.2 & . & & & & 0.2 & 4.9 & . & & 0.4 \\
\hline $\begin{array}{l}\text { Tetrastrum staurogeniaeforme (Schroder) } \\
\text { Lemm. }\left({ }^{*}\right)\end{array}$ & 23.9 & & 0.3 & & & 0.2 & 20.1 & 0.4 & & 0.4 \\
\hline \multicolumn{11}{|l|}{ BACILLARIOPHYCEAE } \\
\hline Cyclotella meneghiniana Kütz & 1.4 & 1.0 & - & 1.5 & . & . & & 2.4 & 2.9 & . \\
\hline C. kutzingiana Thwaites & + & + & & + & . & . & + & . & . & . \\
\hline Cocconeis placentula Ehr. & . & 0.3 & 0.6 & 0.2 & . & . & & . & & 0.4 \\
\hline
\end{tabular}




\begin{tabular}{|c|c|c|c|c|c|c|c|c|c|c|}
\hline \multirow[b]{3}{*}{ Species } & \multicolumn{6}{|c|}{ Site 48} & \multicolumn{4}{|c|}{ Site 53} \\
\hline & \multirow{2}{*}{$\begin{array}{c}1984 \\
\text { March }\end{array}$} & \multirow{2}{*}{$\begin{array}{l}1985 \\
\text { Dec. }\end{array}$} & \multirow{2}{*}{$\begin{array}{c}1986 \\
\text { March }\end{array}$} & \multicolumn{3}{|c|}{1987} & \multirow{2}{*}{$\begin{array}{c}1984 \\
\text { March }\end{array}$} & \multirow{2}{*}{$\begin{array}{l}1985 \\
\text { Dec. }\end{array}$} & \multicolumn{2}{|c|}{1987} \\
\hline & & & & Jan. & March & Sept. & & & Jan. & Sept. \\
\hline Cymbella ventricosa Kütz. & 0.5 & . & 0.3 & & & & & & & \\
\hline C. affinis Kütz. & & $\cdot$ & 0.3 & & & & & & & \\
\hline Diatoma vulgare Bory & & 0.3 & $\cdot$ & & & & & & & \\
\hline D. elongatum (Lyngb.) Agardh & + & & & & & & - & . & . & $\cdot$ \\
\hline Fragilaria construens (Ehr.) Grun. & 0.5 & & 0.3 & . & 0.6 & & . & . & . & 4.1 \\
\hline Gomphonema constrictum Ehr. & & & & & & & . & 0.4 & . & $\cdot$ \\
\hline C. parvulum (Kütz.) Grun. & 1.6 & 0.3 & . & . & . & , & . & 1.2 & . & . \\
\hline Melosira varians C.A. Agardh & 1.9 & + & . & . & . & . & 3.1 & 1.6 & . & . \\
\hline M. arenaria Moore & 0.3 & . & . & . & . & 0.2 & $\cdot$ & $\cdot$ & . & . \\
\hline Navicula accomoda Hust. & 0.5 & . & · & . & . & $\cdot$ & 1.3 & 2.0 & . & . \\
\hline N. bacillum Ehr. & & . & 0.3 & $\cdot$ & . & . & - & - & $\cdot$ & . \\
\hline N. cryptocephala Kütz. & & . & 0.6 & 0.3 & . & . & . & $\cdot$ & 0.3 & . \\
\hline N. capitoradiata Germain & & & & & & & . & 0.4 & $\cdot$ & . \\
\hline N. goeppertiana (Bleisch) H.L. Smith & 0.2 & - & . & . & 0.6 & & · & 0.2 & 0.3 & . \\
\hline N. gregaria Donkin & 2.7 & 0.7 & . & . & . & & 26.3 & - & . & . \\
\hline N. capitata v. hungarica (Grun.) Ross & & 0.3 & . & 0.2 & . & & 0.4 & . & . & . \\
\hline N. lanceolata (Agardh) $\mathrm{Cl}$ & 0.5 & . & . & . & 0.6 & & 0.9 & $\cdot$ & . & . \\
\hline N. pupula Kütz & & 1.0 & . & 0.2 & . & & . & 1.2 & . & . \\
\hline N. subminwcula Manguin & & & & & & & . & 0.4 & . & . \\
\hline N. tripunctata (O.F. Müller) Bory & & & & & & & & & & \\
\hline$N$. trivialis Lange-B. & 0.3 & & & & . & . & . & $\cdot$ & & \\
\hline Nitzschia dissipata (Kütz.) Grun. & & & & & . & . & . & 0.5 & & \\
\hline N. gandersheimiensis Krasskc & & 3.5 & 0.8 & 0.7 & . & . & . & 5.6 & & \\
\hline N. gracilis Hantzsch. & 0.8 & 1.7 & & 0.2 & . & . & 0.9 & 2.8 & & \\
\hline N. amphibia Grun. & & 1.0 & & & . & . & . & 2.4 & & \\
\hline N. umbonata (Ehr.) Lange-B. & & & & & . & . & . & 1.2 & & \\
\hline N. palea (Kütz.) Grun. & 7.8 & & 1.7 & 1.2 & 0.6 & 0.2 & 2.2 & . & 0.3 & \\
\hline N. pusilla Kütz. & & & 0.28 & & & & & & . & \\
\hline$N$. sigma (Kütz.) W. Smith & & & & & & & & & 0.3 & \\
\hline $\begin{array}{l}\text { Stephanodiscus minutulw (Kütz.) } \\
\text { Cleve \& Moller }\end{array}$ & & & & & & & & 0.4 & & \\
\hline $\begin{array}{l}\text { S. hantzschii f. tenuis (Hust.) Håkansson \& } \\
\text { Stoermer }\end{array}$ & . & & & & 0.6 & 0.2 & & & & \\
\hline S. rotula (Kütz.) Hcndey & + & & & & + & + & . & . & . & . \\
\hline Synedra ulna (Nitzsch.) Ehr. & 0.3 & 0.7 & 0.3 & 0.5 & 1.3 & . & . & 3.2 & 0.3 & . \\
\hline DIVERSITY $(\mathrm{H})$ & 1.44 & 0.55 & 0.46 & 0.71 & 0.4 & 1.34 & 1.1 & 1.18 & 1.17 & 1.48 \\
\hline
\end{tabular}

be assumed that they are euplankters. Among the Chlorophyceae, the following were the most abundant: Coelastrum microporum, Kirchneriella subcapitata, Scenedesmus brevispina, S. quadricauda, Tetraedron triangulare and Tetrastrum staurogeniaeforme. Of the diatoms, only seven species belonged to the centric group: Cyclotella meneghiniana, C. kutzingiana, Melosira varians, M. arenaria, Stephanodiscus hantzschii f. tenuis, S. minutulus, and S. rotula (fig. 2). Moreover, in contrast with other rivers (DESCY, 1987; KIss, 1987; Lange-Bertalot, 1974), centric diatoms were not abundant. C. meneghiniana and $\boldsymbol{M}$. varians were the most important, but they never exceeded the $3 \%$ of any sample.

Cyanophyta were not important in the samples at any time. Merismopedia tenuissima was the most constant species of the group, but it never reached important numbers (table 2). Two species of bacteria (Sarcina maxima Lindner and Sphaerotilus natans Kütz.) were microscopically observed in the proximity of the city of Girona in high numbers. Their presence in the phytoplankton samples is likely caused by pollution. Cryptophyceae or 
chrysophyceae, two groups that are frequent in the plankton elsewhere (BAKER \& BAKER, 1981; Holmes \& WhitTon, 1981) were not found in the Ter.

The dominant diatom species were pennales. These species were not abundant, except in spring of 1984, where Navicula gregaria, a species that is very frequent in estuarine habitats (Mc INTIRE, 1973; Riaux \& GERMAin 1980), comprised $27 \%$ of the sample at site 53. The relative abundance of diatoms decreased from spring to summer, probably because as the water becomes slower these species settle out of suspension. This assumption is in agreement with the live/dead diatoms ratio. In winter and spring 48-70 percent of the total diatoms were dead, while in summer this percentage never reached $5 \%$.

Chlorophyceae (green algae) were the most important taxonomic group. Thirteen taxa of Scenedesmus were recorded in the phytoplankton (fig. 2), mainly during summer. None of these species was abundant, and in total they never comprised more than $3 \%$ of all cells. Other green algae were more abundant; in the outflow of the reservoirs, Chlorella reached abundances of 99 percent of the total, Ankistrodesmus falcatus and Chlorella vulgaris accounted for 36 to 88 percent of the total cell number over the whole study period, except in the summer, when previously absent species appeared (Micractinium pusillum, Oocystis lacustris ), and others such as Kirchneriella subcapitata and Monoraphidium contortum increased in number.

\section{DISCUSSION}

Some occasional growths of phytoplankton were detected in the river Ter. In quiet areas, such as at the output of El Pasteral reservoir, a poorly developed assemblage was found. Physical conditions favourable to plankton development should also occur near Girona, but pollution from the city probably limited the development of the plankton. A true phytoplankton community in the river Ter developed only in the vicinity of the mouth.

Benthic communities had a great influence on the Ter plankton assemblages. Euplanktonic cen- tnc diatoms were never abundant. The most common euplanktonic taxa were the green algae. Benthic species were most important in winter and spring because of the higher water flow, and at shallow areas, such as site 53. Switches from green algae to diatoms in time was irregular in the Ter.

In other lotic ecosystems such switching has been described (BAKER \& BAKER, 1981; DESCY, 1987; Pinter \& Backhaus, 1984; Williams \& Scott, 1962), with centric diatoms being abundant during winter and autumn (FRIEDRICH \& MülLER, 1984; LACK 1971), when the water velocity is higher, and the water is colder and comparatively poorer in nutrients. Switching between centric diatoms and green algae has been observed in larger Mediterranean rivers (ANDREOLI \& FricaNo, 1981; CAPBLANC \& DAUTA, 1978). It is therefore likely that the striking absence of centric diatoms in the Ter is caused by its short length and the moderate basal flow. At the same time, low water speed probably favours the Chlorophycean developmert in summer.

DESCY's (1987) classification of European rivers stressed the difference between the fast-flowing rivers, in which pennate diatoms dominate (i.e., a striking benthic influence) and green algae are characteristically poorly developed (rarely exceeding 1000 per $\mathrm{ml}$ ), and the slow-moving, nutrientrich, large rivers where centric diatoms are dominant, and in which green algae are abundant in the summer. In the latter rivers cell densities reach 10,000 to 100,000 per $\mathrm{ml}$, and the number of species and the diversity are also high. In the lower stretch of the Volga river 179 species have been observed (KuZMIN, 1978), and more than 200 have been observed in the Bristol Avon (Moore, 1976), in the Po (Andreoli \& Fricano, 1981) and in the Meuse (Descy 1987). The Ter, because its short length, has a low species number (seventy two taxa). Its high cell density (reaching sometimes up to 100,000 individuals) does not seem to fit with either of Descy's two classes. Medium-sized Mediterranean rivers, such as the Ter, are able to develop an euplanktonic community, but its character lies between those of the fast-flowing, mediumsized rivers and the large rivers found in other parts of Europe. It appears the richness in nutrients and the irregularity of flow peaks combine to produce these unique characteristics. 


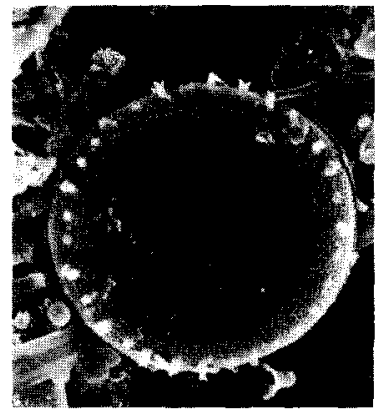

1

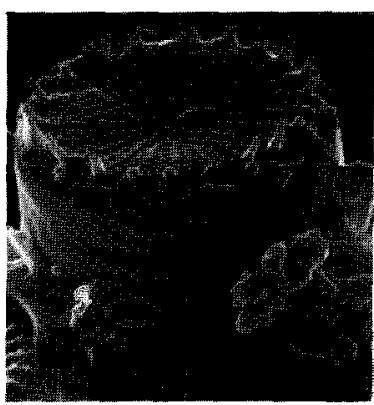

4

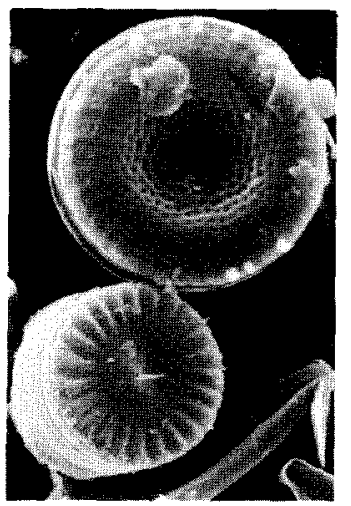

7

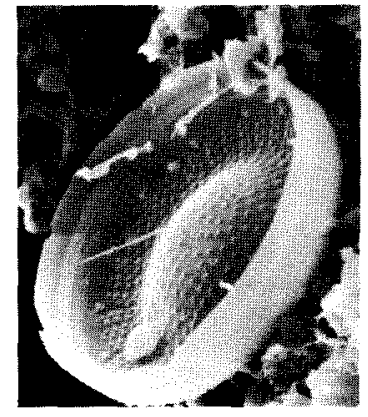

2

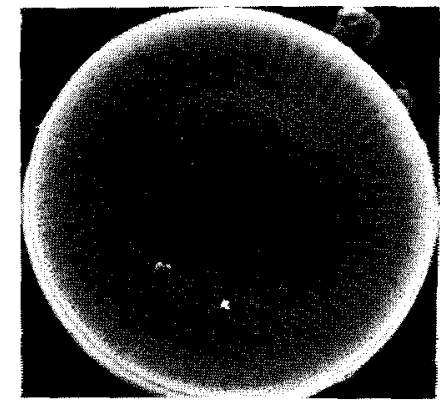

5

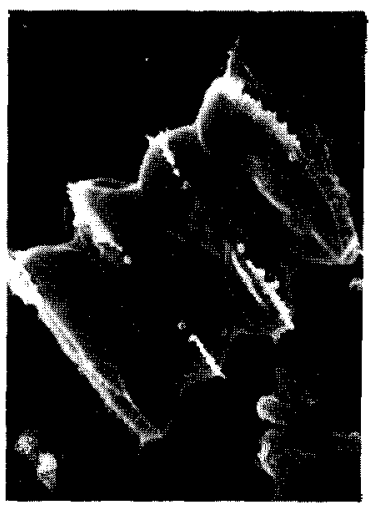

8

3

9
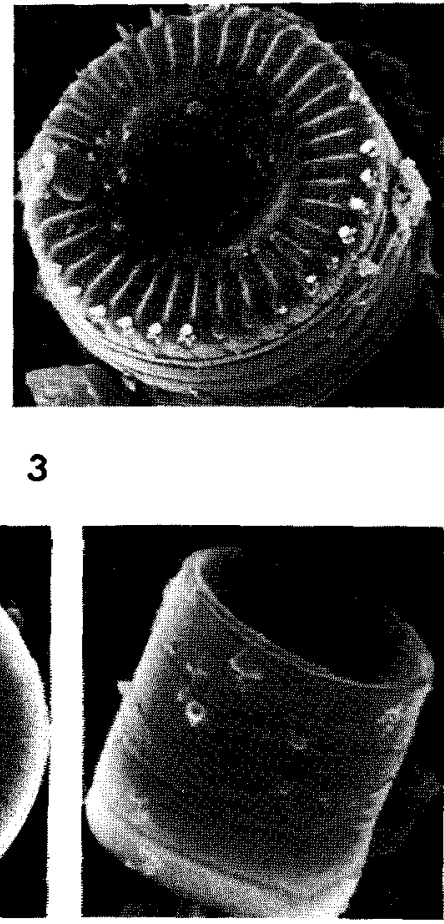

6

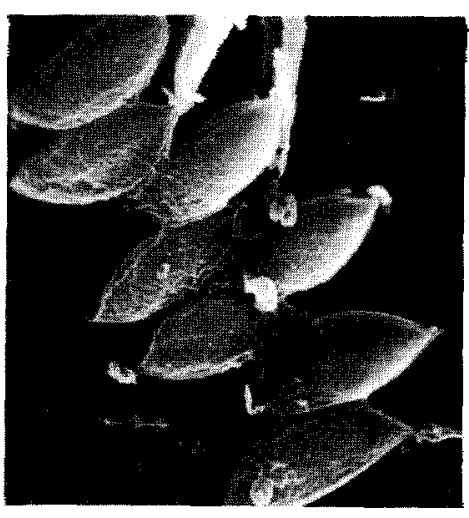

Figure 2.- SEM observations of some taxa of the Ter phytoplankton. 1. Stephanodiscus hantzschii f. tenuis, outside $(\times 2000) .2$. Stephanodiscus hantzschii f. tenuis, inside $(\times 2200)$. 3. Cyclotella meneghiniana $(\times 2400)$. 4. Stephanodiscus hantzschiif. tenuis, outside $(\times 4600)$. 5. Cyclotella kutzingiana $(\times 3000)$. 6. Melosira varians $(\times 1900)$. 7. Cyclotella meneghiniana (lower) and Stephanodiscus rotula (upper) $(\times 1900)$; note on the latter the black arrow indicating the strutted process, characteristic in this species. 8. Scenedesmus armatus (about $\times 2000$ ). 9. Scenedesmus acutus v. globosus (about $\times 2000$ ).

Observación de algunos táxones del fitoplancton del no Ter mediante el microscopio electrónico de barrido. 1. Stephanodiscus hantzschii f. tenuis, exterior $(\times 2000)$. 2. Stephanodiscus hantzschiif. tenuis, interior $(\times 2200)$. 3. Cyclotella meneghiniana $(\times 2400)$. 4. Stephanodkcus hantzschii f. tenuis, exterior $(\times 4600)$. 5. Cyclotella kutzingiana $(\times 3000)$. 6. Melosira varians $(\times 1900)$. 7. Cyclotella meneghiniana (inferior) y Stephanodiscus rotula (superior) $(\times 1900)$; nótese en la superior la flecha negra indicando el proceso valvar interno característico en esta especie. 8. Scenedesmus armatus (aproximadamente $\times 2000$ ). 9. Scenedesmus acutus v. globosus (aproximadamente $\times 2000$ ). 


\section{ACKNOWLEDGEMENTS}

Financial support of this work has been provided by the CAICYT (project number 478181). The
Microscopical Service of the University of Barcelona provided facilities and technical assistance for the scanning observations. I am indebted to Dr. E. Fee and Dr. D. Planas for their suggestions and critical improvements to the manuscript.

\section{RESUMEN \\ COMPOSICIÓN DEL FITOPLANCTON EN UN RÍO MEDITERRÁNEO DE TAMAÑO MEDIO: EL TER}

Se ha observado desarrollo de fitoplancton en segmentos remansados del río Ter (Catalunya, NE España). Las poblaciones verdaderamente planctónicas aparecieron restringidas a las cercanías de la desembocadura. La presencia de diatomeas céntricas fue limitada, mientras que las diatomeas bentónicas fueron predominantes. Las algas verdes fueron el grupo taxonómico más importante del fitoplancton del río.

Las poblaciones de fitoplancton del río Ter poseen características intermedias entre los ríos de corriente rápida, con pobre desarrollo de organismos, y los enlentecidos y con elevadas densidades de organismos. Su mediano tamaño y las concentraciones elevadas de nutrientes son los principales factores causales de estas peculiares características.

\section{BibLiography}

Andreoli, C. \& G. Fricano, 1981. Variazione stagionali del fitoplancton nel tratto medio del Po interessato dalla construenda centrale termonucleare di Caorso (Piacenza). Riv. Idrobiol. 20 (1): 139-152.

APHA (American Public Health Association), 1980. Standard methods for examination of water and wastewater. 15 th ed. (APHA). Washington. 1134 pp.

BAKER, K.K. \& A.L. BAKER, 1981. Seasonal succession of the phytoplankton in the upper Mississippi river. Hydrobiologia 83: 295-301.

Capblanc, J. \& A. DautA, 1978. Phytoplancton et production pnmaire de la rivière Lot. Annls. Limnol. 14 (1-2): 85-112.

Dauta, A., 1975. Étude du phytoplancton du Lot. Annls. Limnol. 11: 219-238.

DEscy, J.P., 1987. Phytoplankton composition and dynamics in the nver Meuse (Belgium). Arch. Hydrobiol. Suppl. 78 (2): $225-245$

DOBler, E. \& A. SCHMIDT, 1980. Weiters vergleichende Beitrage zur Kenntnis limnologischer Verhaltnisse der Donau und Theiss. Tiscia 15: 45-81.

Friedrich, G. \& D. Müller, 1984. Rhine. In: B.A. Whitton (ed.), Ecology of European rivers: 265-315. Blackwell Sc. Publ., Oxford.

Geitler, L., 1932. Cyanophyceae. In: L. Rabenhorst (ed.), Kryptogarnenflora von Deutschland, Osterreich und der Schweiz. 1196 pls. Leipzig.

Germain, H., 1981. Flore des diatomées (Diatomophycées). Eaux douces et saumâtres du Massif Armoricain et des contrées voisines d'Europe Occidentale. N. Boubée, 443 pls. Paris.
Holmes, N.H.T. \& B. A. WhitTon, 1981. Phytoplankton of four rivers: the Tyne, Wear, Tees and Swale. Hydrobiologia 5: 257-289.

HYNES, H.B.N., 1970. The ecology of running waters. Liverpool University Press, 555 pls.

KIss, K. T., 1987. Phytoplankton studies in the Szigetkoz section of the Danube dunng 1981-1982. Arch. Hydrobiol. Suppl. 78, 2 (Algological Studies 47): 247-273.

KLEE, R. \& CH. STEINBERG, 1987. Kieselalgen Bayenscher Gewasser. Znformationsberichte Bayer. Landesamt für Wasserwirstchaft 4187.

KomareK, J. \& B. FotT, 1983. Chlorophyceae (Grünalgen). O. Chlorococcales. In: G. Huber-Pestalozzi, Das Phytoplankton des Süsswassers. Verlagsbuchhandlung, 1044 pls. Stuttgart.

Krammer, K. \& H. Lange-Bertalot. 1986. Bacillariophyceae. I. Naviculaceae. In: E. Ettl, J. Gerloff \& H. Heynig (Eds.), Süsswasserflora von Mitteleuropa. Gustav Fischer Verlag, 876 pls. Stuttgart.

Kuzmin, G.V., 1978. Phytoplankton of the Volga. In: Ph. D. Mordukhai-Boltovskoi (Ed.), The river Volga and its life. Junk Publishers, The Hague.

LACK, T. J., 1971. Quantitative studies on the phytoplankton of the nver Thames and Kennet at Reading. Freshwat. Biol. 1: 213-224.

LANGE-BERTALOT, H., 1974. Das phytoplankton im unteren Main unter dem Einfluss starker Abwasserbelastung. Cour. Fosch. Int. Senckenberg 12: 1-88.

Margalef, R., 1983. Limnología. Ed. Omega, Barcelona. $1010 \mathrm{pp}$.

Mc INTIRE, D., 1973. Diatom associations in Yaquina estuary, Oregon: a multivariate analysis. J. Phycol. 9: 254-259. 
MoORE, J.W., 1976. Seasonal succession of algae in rivers I. Examples from the Avon, a large slow-flowing river. J. Phycol. 12: 342-349.

Peelen, R., 1975. Changes in the composition of the plankton of the rivers Rhine and Meuse in the Netherlands during the last fifty-five years. Verh. int. Ver. Limnol. 19: 19972009.

Pinter, I. \& D. Backhaus, 1984. Neckar. In: B.A. Whitton (Ed.), Ecology of European Rivers: 317-344. Blackwell Scientific Publications, Oxford.

RiauX, C. \& H. Germain, 1980. Peuplement des diatomées epipéliques d'une slikke de Bretagne Nord. Cryptogamie: Algologie 1 (4): 265-279.

SABATER, F., 1987. Estudi integrat del riu Ter i la seva conca. Ph. D. dissertation. Univ. of Barcelona. 321 pp.
SABATER, S., 1989. Encrusting assemblages in a Mediterranean nver basin. Arch. Hydrobiol.

SABATER, S., 1990, Composition and dynamics of a highly diverse diatom assemblage in a limestone stream. Hydrobiologia.

SAbAter, F. \& J. ARmengol, 1988. Chemical characterization of the river Ter. Limnetica (in press).

SABATER, S. \& F. Sabater, 1988. Diatom assemblages in the river Ter. Arch. Hydrobiol. 111 (3): 397-408.

SHANNON, C.E.\& W. WEAVER, 1963. The mathematical theory of communication. University of Illinois Press.

SkUlBerG, O.M. \& A. LILLEHAMmER, 1984. Glåma. In: B.A. Whitton (Ed.), Ecology of European Rivers: 469-498. Blackwell Scientific Publications, Oxford.

Williams, L.G. \& C. Scotr, 1962. Principal diatoms of major waterways of the United States. Limnol. Oceanogr. 7 (3): $365-379$. 